\title{
The Facts of Mahur Maqam With Respect to Musical Creations of Abdulbaki Nasir Dede, Hasim Bey and Huseyin Sadettin Arel; Intellectual and Historical Projections
}

\author{
Sami Dural \\ Istanbul Medeniyet University, Faculty of Art, Design and Architecture, \\ Department of Turkish Music, Musicology Department, Istanbul, Turkey \\ E-mail: udsamidural75@gmail.com \\ Erdal Kilic \\ Istanbul Medeniyet University, Faculty of Art, Design and Architecture, \\ Department of Turkish Music, Musicology Department, Istanbul, Turkey \\ E-mail: rdlklc@hotmail.com
}

\begin{abstract}
The Mahur sound which is one of the determinative colors of today's Turkish music has been an aesthetic fact, towards which musical composers, who lived in different societies and periods, approached with their own specific manners. The motives forming the shape of this aesthetics are individual existences establishing relationships with the said social-periodical facts. Abdülbâkî Nâsır Dede (1765-1821), Hâşim Bey (1815-1868) and Hüseyin Sadettin Arel (1880-1955) who proved their existence with their musical creations and thus, could make visionary moves, defined the Mahur maqam with their unique nuances. Nâsir Dede approached to the Mahur maqam in the mysterious world of lahn (errors of speech) which belongs to the world of meanings of Yenikap1 Mevlevihane and in this context, arranged the relationships of musical intervals according to the features of tune structures determined by masters of music. Haşim Bey approached to the Mahur maqam within the musical expression style of Western culture which was began to be understood and compared by the individuals of Tanzimat Reform Era. Accordingly, the Mahur maqam corresponds to the sol major in the European style in a sense. In this context, according to Hüseyin Sadettin Arel, the Mahur maqam is similar to major, but as different from major it is a structure dominated by Çargah tunes containing T-T-B-T intervals. For Arel, the said intervals are musical materials which can adapt to modern mind and emotion definitions of nation-state citizens of the Republic. In this respect, the Mahur maqam constitutes a structure having different effects other than the effect area of major. Arel, thus, claims that Turkish music has its own national materilals which are candidate for universality such as Çargah, Buselik, Kurdi, Rast, Uşşak, Hicaz obtained from the nature against the major-minor of the West. Through the article study, the Mahur maqam is questioned intellectually interacted with the perspectives where historicity begins to form which includes society and individual facts in the the triangle of said people's creations.
\end{abstract}

Keywords: Abdülbâkî Nâsır Dede, Hâşim Bey, Hüseyin Sadettin Arel, Mâhur, Musical Creation, Intellectuality, Historical, Community, Individuality.

DOI: $10.7176 / \mathrm{JSTR} / 5-5-08$

\section{Abdülbâkî Nâsır Dede, Hâşim Bey ve Hüseyin Sadettin Arel'in Müzikal Yaratımları Bağlamında Mâhur Makamının Serencamı; Düşünsel ve Tarihsel İzdüşümler}

Özet

Günümüz Türk müziği ses dünyasının belirleyici renklerinden olan Mâhur duyumu, farklı toplumsallıklarda ve dönemlerde yaşamış olan müzik yaratıcılarının kendilerine has yaklaşımlar sergiledikleri estetik bir olgu olmuştur. Bu estetiğin niteliğini şekillendiren sâikler ise söz konusu toplumsal-dönemsel gerçekliklerle ilişkiler kuran bireysel varoluşlardır. Müzikal üretimleriyle 
varlıklarını ortaya koymuş ve bu itibarla öngörüsel hamlelerde bulunabilmiş olan Abdülbâkî Nâsır Dede (1765-1821), Hâşim Bey (1815-1868) ve Hüseyin Sadettin Arel (1880-1955) Mâhur makamını kendilerine has nüanslarla tanımlamışlardır. Nâsır Dede, Mâhur makamını, Yenikapı Mevlevîhânesi’nin anlam dünyasına ait olan lahn olgusunun sırlı dünyasında ele almış ve bu anlamda müzikal ses aralıklarının birbirleriyle ilişkilerini, nağme yapılarının mûsıkî üstadlarınca belirlenen işlevlerine göre düzenlemiştir. Hâş̧im Bey ise Mâhur makamını Tanzimat Dönemi bireyinin algılamaya ve kıyaslamaya başladığı Batı kültürünün müzikal ifade tarzı dahilinde ele almıştır. Buna göre Mâhur makamı bir yönüyle alafrangadaki sol majöre karşıllk gelir. Bu bağlamda Hüseyin Sadettin Arel'e gelindiğinde Mâhur makamı artık majörün benzeri olan fakat majörden farklı olarak T-T-B-T aralıklarını haiz Çârgâh renginin hakim olduğu bir yapıdır. Arel için söz konusu aralıklar Cumhuriyet'in ulus-devlet vatandaşlarının çağdaş zihin ve duygu tanımlamalarına uyum sağlayabilecek müzikal malzemelerdir. $\mathrm{Bu}$ itibarla Mâhur makamı majörün etki sahasının dışında farklı tesirlere sahip bir yapı arz eder. Arel böylelikle Batı'nın majör-minörüne karşllık Türk müziğinin tabiattan sağlanan Çârgâh, Bûselik, Kürdî, Râst, Uşşâk, Hicâz gibi evrensilliğe namzet milli malzemelere sahip olduğunu iddia eder. Makale çalışması boyunca Mâhur makamı, düşünsel anlamda toplum ve birey olgularını içeren tarihselliğin şekillenmeye başladığı perspektiflerle etkileşim içerisinde, adı geçen müzik insanlarının yaratımları üçgeninde sorgulanmaktadır.

Anahtar Kelimeler: Abdülbâkî Nâsır Dede, Hâşim Bey, Hüseyin Sadettin Arel, Mâhur, Müzikal Yaratım, Düşünsellik, Tarihsellik, Toplumsallık, Bireysellik.

\section{Giriş}

Descartes'ın özne-nesne düalizmi bağlamında ayrıcalıklı bir konum kazanan düşünen özne, yine Tanrısal bir zeminin referanslı̆̆ında da olsa, doğa üzerinde eyleme özgürlüğünü kazanmıştı. Mekanist dünya görüşü bağlamında bu özgürlüğün en önemli iddiası kutsallıktan arındırdığı doğa ile ilişkiye girecek olanın, cogito ergo sumun Kartezyen öznesi olduğuydu. Söz konusu iddia her ne kadar nesnellik perspektifini miras alsa da evrenselliğin epistemolojik kurulumunda bir merkez kayması oluş̧urmuş ve belirleyiciliği, gerçekliği temsil edebilme kudretini haiz zihinsel platforma devretmişti. Temsilin akıl çerçevesinde anlamlandırılan tarih, zaman vb. olgularının araçsallıklarına koşut asıl önemli olan ise bu noktadan itibaren söz konusu saiklerin kritik edilebilme imkanına kavuşmuş olmalarıydı. Bu doğrultuda Kant, insanın teorik akılla bilebileceği şeyin ancak fenomenal nitelikte olabileceğini, bilgiyle muhataplığın ancak insanın iç duyumunun apriori koşulunu oluşturan zaman ve mekan olguları dahilinde gerçekleşebileceğini belirtmekteydi. Böylelikle zaman olgusu insanın dışındaki konumdan zihinsel kategori boyutuna taşınmış olmaktaydı. Bu durumun en dikkat çekici tarafi, zihnin oluşturucu yanının gündeme gelmesiydi. Buna göre insan, pratik aklın koşulsuz buyruğu dahilinde ahlakî eylemlerde bulunarak gerçekliği oluşturmaktaydı.

Kant'in kritiğiyle birlikte gerçeklik, bilgi vb. olgular insansal bir nitelik kazanmıştır. Bu niteliğin, bilinçler arası ilişkiye konsantre olunarak diyalektik bir zeminde tanımlanan tarihsellik bağlamında ele alınması ise Hegel tarafindan gerçekleştirilmiştir. Hegel'in, gerçekliğin ele alınmasında adres gösterdiği bu tarihsel zemini Bumin (2013) şu şekilde açıklamaktadır:

İnsanın özbilinç olmasının yolu istekten geçtiğine ve isteyen ben'e içeriğini kazandıran şey, yöneldiği nesne olduğuna göre, insanın özbilinç olmasının tek yolu isteğinin doğal olmayan bir nesneye yönelmesidir. Bu nesne verilmiş bir varlık olursa, böyle bir varlı̆̆ istemek kendini onunla doldurmak, ona benzemek ve ona bağlanmak demek olacaktır. O halde özerk bir varlık, bir özbilinç olmak için, yani insanın kendi doğal, verilmiş varlığını aşması için, istek, şu an için mevcut biricik doğal olmayan, "var olmayan” ş̧eye, isteğin kendisine yönelmeli, başka bir isteği, başka bir ben'i istemelidir (s. 30).

Aktarılan bu ifadelerden de anlaşılacağı üzere Hegel, doğal olmayana yönelmeye yaptığı vurguyla tine dikkat çekmiş ve bu tin bağlamında bilinçler arası somut ilişkiyi önceleyen bir tarihselliği kurmuştur. Ancak eylemsel olanın düşünsel olanla eşzamanlı olarak değerlendirildiği bu diyalektik sentez farklı yaklaşımlar tarafindan kritik edilmiş ve Nietzsche gibi bir isim tarihin, düşünsel olanın merkezîliğinde ele alınmaması gerektiğinin altını çizmiştir. Nietzsche'ye göre tarih; aşkın bir düzlemin ereksel anlam dünyasına ait değildir, oluşun (oluşturuculuğun) aktif yaşantısıdır. Nietzsche'nin söz konusu tarih anlayışını Küçükalp (2008) şu şekilde dile getirir: 
Tarihi, kaynağa yönelik bir araştırma olarak ele almayan Nietzsche'nin jeneolojisi... hakikat-yanılsama ayrımını, bütün bilgimizin haksızlığa dayandığını göstermek suretiyle temelsiz kılar. Jeneoloji insanî kendiliklerin kökenlerini keşfetmeyi değil, kendileri aracılığıyla insan varlıklarının bir özne olarak yaratılmış oldukları değişik modları oluşturmanın yollarını arar. Kökenlere yönelik her araştırmanın özler ve kendilikler varsayması nedeniyle jeneoloji, tarihsel olayların tekilliklerini, bütün rastlantısallıkları ve katiyet eksiklikleriyle kaydetme çabası güder (s. 86).

Tüm bu düşünce perspektifleriyle etkileşim içerisinde, makale çalışması, konu edindiği isimlerin müzikal yaratımlarının, belirli toplumsal ve bireysel düzlemlerin düşünsel-eylemsel olguları olarak sorgulanması gerektiğini düşünmektedir. Abdülbâkî Nâsır Dede, Hâşim Bey ve Hüseyin Sadettin Arel'in, Mâhur makamı özelinde ortaya koymuş oldukları perspektiflerin süreklilikleri ve kopuşları içermeleri, aynı makam üzerinde en nihayetinde farklı değerlendiriş ve anlatım tarzlarına sahip olmaları, kendileri ele alınırken düşünsel anlamda sabit, değişmez, metafiziksel bir referans noktasından ziyade yukarıda kısaca mahiyetleri aktarılan düşünce sistemleriyle etkileşime girilmesini gerektirmektedir. $\mathrm{Bu}$ etkileşimin sınırları ise makale çalışması boyunca sorgulama eyleminin kendisine has vurgu noktaları tarafından belirlenmektedir. Buna göre makale çalışmasının, söz konusu düşünce sistemleriyle ortak paydaya sahip olduğu nokta, belirli eleştirel süreçlerle ortaya çıkmış olan tarih mottosuna ayırmış olduğu ilgidir. $\mathrm{Bu}$ ilginin niteliği sorgulama çerçevesinde farklılaşmakta, tarih özsel, bilinçsel, oluşsal vb. zeminlerle eşzamanlı ele alınmamakta, bunun yerine Mâhur makamı özelinde ortaya konulan yaratımlarla yüzleşmeye konsantre olunmaktadır. Müzikal yaratımın tarih nezdinde ele alındığ 1 bağlam ise toplum ve birey ilişkileridir.

\section{Bulgular}

\subsection{Abdülbâkî Nâsır Dede}

Abdülbâkî Nâsır Dede (1765-1821), Râst makamının temel unsurlarını1 şu şekilde tanımlar: "Râst; perdei râstdan ${ }^{2}$ âgâz idüp, dügâh ve segâh ve çârgâh perdesi dönüp aşağı segâh ve dügâh perdesi ile râst perdesine gelüp ânda karâr ider" (Abdülbâkî Nâsır Dede, nr: 1242/1, s. 9-b, 10-a). ${ }^{3}$ Nâsır Dede'nin Râst makamıyla birlikte diğer tüm makam ve birleşimlerde kullandığ 1 ses malzemelerinin (perdeler) kaynağ1 "siyâgat-1 mûsikî"dir (nr: 1242/1, 3b). ${ }^{4}$ Müzikte söz sahibi olmuş üstadları vurgulayan bu perspektife göre söz konusu ses malzemesi, ney enstrümanının dügâh, kürdî, segâh, çârgâh, sabâ, nevâ, aşîrân olarak isimlendirilen yedi deliği üzerinden ve neyzenin üfleyiş üslûbuna göre anlamlandırılır. Nâsır Dede'nin Terkîbât bölümünde tanımladığı Mâhur-ı sagîr, Mâhur-ı kebîr, Mâhurek ve Mâhur-ı kebîr-i kadîm birleşimleri de yukarıda bahsedilen zeminden hareketle şekillendirilmiştir.

Nâsır Dede, Mâhur-1 sagîr birleşimini şu şekilde tanımlar:

Mâhur-1 sagîr; gerdâniyye perdesinden Râst âgâze idüp nevâ perdesine geldikde çârgâh perdesini gösderüp ânda karâr ider. Bunda kudemâ-i müteahhirîn ve kudemâ beyninde ihtilâf yoktur. Ammâ fî zemâninâ müstakil isti'mâlden mehcûrdur (nr: 1242/1, 18-a).

Tanımdan anlaşıldığı gibi söz konusu birleşim, Nâsır Dede'nin zamanında müstakil olarak kullanılmamakla birlikte önceki dönemlerdeki müzik üstadlarının üzerinde hemfikir oldukları bir yapıdır. Buna göre Mâhur-1 sagîr, nevâ perdesi üzerinde Râst lahninin ses aralıklarını içerir. Bu lahnin perdelerinin râst, dügâh, segâh, çârgâh olması hasebiyle Mâhur-1 sagîr'de nevâ üzerinde kullanılan perde de evc olmaktadır. ${ }^{5}$ Nâsır Dede'nin, III. Selim'in cesaretlendirmesiyle ve emriyle kaleme almış olduğu

${ }^{1}$ Nâsır Dede’ye göre makamın temel unsuru; “... uygun bir yol ile temel unsurlarının ișitilmesiyle kendine özgü bir bütünlük taşıyıp, başka kısımlara bölünmesi mümkün olmayan ezgi”'dir (Başer, 2013, s. 107). Tedkîk u Tahkîk'te lahn olarak isimlendirilen bu yapı makam tanımlamaları esnasında ek nameler alır. Nâsır Dede bu ek nameleri "lâzım" ve "gayr-ı lâzım” olarak "müzeyyin" (Abdülbâkî Nâsır Dede, nr: 1242/1, s. 9-a) kavramı altında siniflandirır.

${ }^{2}$ Makalede makam isimleri büyük harfle, perde isimleri küçük harfle yazılmıştır.

${ }^{3}$ Söz konusu eserin devam eden alıntılarında kaynak kullanımı numara ve sayfa gösterimi şeklinde olacaktır.

${ }^{4}$ Nâsır Dede; "Pes siyâgat-ı mûsikî Hz. Adem'den berû vardır” ifadesiyle müzik üstadlı̆̆̆ olgusunu tarihsel bir kökene oturtur.

${ }^{5}$ Nâsır Dede, perdeler arasındaki ilişkilerden bahsederken; “... nevâdan tiz hicâza kadar siralanan perdeler"'in "yegâhtan hicâza dek birbirinin karşılı̆̆l” (Başer, 2013, s. 105) olduğunu belirtir.

59 | P a g e

www.iiste.org 
Tedkîk u Tahkîk'te Mâhur-1 kebîr makamı da Mâhur-1 sagîr ile irtibatlı olarak tanımlanmıştır. Bu bağlamda, Mâhur-1 kebîr; "Mâhur-1 sagîr âgâz idüp Râst karâr ider" (nr: 1242/1, 18-a). Nâsır Dede, Mâhur-1 kebîr' in, kendisinden öncekiler ${ }^{6}$ tarafindan Gerdâniye olarak isimlendirildiğini aktarır.

Evc perdesinin mâhur perdesi ile değiştirilerek kullanıldığ 1 birleşim ise Mâhûrek ismi ile nitelendirilmiştir. Nâsır Dede bu birleşimin "bazı bestelerde işitilmiş olup, bu isimle yazıldı" ğını (Başer, 2013, s. 207) belirtmiştir. Buna göre Mâhûrek şu şekilde tanımlanmıştır: "Muhayyer perdesinden nevâ perdesine dek su'ûden ve hübûtan Pençgâh-1 asl resmi üzre seyr idüb gerdâniyye perdesinde karâr ider" (nr: 1242/1, s. 33-b). Bu birleşimin tanımında geçen Pençgâh-1 asl birleşiminin yapısı ise aşağıda aktarıldığı gibidir:

Pençgâh-1 asl; Uşşâk âgâze idüb râst perdesinde karâr ider. Lâkin Râsta müşâbeheti ihtirazından iktizâ ettiği halde hüseynî perdesinden mâ'adâ müzeyyin, metruk ve iktifaya mahmuldür. Ve Râstdan âgâz perdesiyle mefrûkdur. Ve bu terkîb içün kudemâ-i müteahhirîn ve kudemâ beyninde hilâf yoktur. Ammâ ba'zlları inkâr eder ise isti'mâl olunan tasnîf-i kadîme-i mu'tebere isbâtına delil-i kavîdir (nr: 1242/1, s.17b).

Pençgâh-ı asl'ın yukarıda aktarılan tanımı dikkate alındığında nevâ üzerindeki müzik cümlelerinde yine evc perdesinin kullanıldığı anlaşılmaktadır. Mâhûr-1 kebîr-i kadîm birleşimi de Mâhûr-1 sagîr icrâ ederek evc perdesinin kullanımını gerektirmektedir. Ancak söz konusu birleşim çârgâh perdesine geldiğinde segâh perdesi yerine buselik perdesi kullanarak farklı aralık duyumlarını da içerecek bir şekle dönüşür. Birleşimin kararı ise yine Râst makamıyla gerçekleştirilir. Böylece birleşimin karar bölgesinde dügâhsegâh perdelerinin içerdiği aralıklar dışında dügâh-bûselik perdelerinin aralıkları da gösterilmiş olmaktadır. Nâsır Dede'nin, dönemindeki "bestelerde mevcut” (Başer, 2013, s. 207) olup icrâcıların arasında tanınmadığını belirttiği bu birleşimin tanımı aşağıdaki gibidir:

Mâhûr-1 kebîr-i kadîm; Mâhûr-1 sagîr âgâze idüb karârgâhı olan çârgâh perdesine geldikde segâh perdesinin bûselik perdesine tebdil ile hübûtan Râst âgâze idüp karâr ider. Kudemânın ve kudemâ-i müteahhirînin bunda ihtilâfı yoktur (nr: 1242/1, s. 33-b).

Nâsır Dede, lahn kavramı bağlamında müzikal estetikte yatay harakete konsantre olmuş, Yenikap1 Mevlevîhânesi'nde neyzenlik yapmış bir karakter olarak makamsal yapılarda perdelerin nağmeler tarafindan belirlenen fonksiyon ve derecelerine önem vermiştir. Burada söz konusu olan, seslerin dikey bağlamdaki uyumu yani armoni çerçevesindeki ilişkileri değil, Nâsır Dede ve toplumsal örgütlenmesinin pratik bilgeliklerini yansıttıkları ve esrârdan haber veren lahn olgusudur (Bkz. Şekil 1).

${ }^{6}$ Nâsır Dede, kendisinden önceki dönemlerin müzik yazarlarını "akdemûn, kudemâ, müteahhirîn, kudemâ-i müteahhirîn" (nr: 1242/1, s. 4-a, 5-a), "mütekaddimîn-i selef (nr: 1242/1, s. 30-b), kudemâ-i selef (nr: 1242/1, s. 26-b), selef (nr: 1242/1, s. 19-a), müteahhirîn-i selef” (nr: 1242/1, s. 19-b) gibi isimlerle sinıflandırmıştır. Yukarıda bahsi geçen Mâhur-ı sagîr ve Mâhur-ı kebîr birleşimlerinde zikredilen önceki dönem müzik yazarları kudemâ ve kudemâ-i müteahhirîndir. Yalçın Tura söz konusu sinıflandırmayı şu şekilde yorumlamıştır: "Abdülbaki Dede, kesin bir tarihlendirme yapmamakla birlikte, bize birtakım ipuçları veriyor. Bu ipuçlarından hareketle, Farabi'ye kadarki dönemin nazariyatçılarını 'akdemûn', Safïuddîn'i ve onun yolundan gidenleri 'kudemâ', II. Murad ve Fatih dönemi nazariyatçılarını 'kudemâ-i müteahhirîn', Lâdikli Mehmet Çelebi'yi ve ondan sonra gelenleri 'müteahhirîn' daha sonrakileri 'eslâf', Nâŷ̂ Osman Dede ve Kantemiroğlu'nu 'müteahhirîn-i selef' ve III. Selim dönemini 'fî zemâninâ' sayabiliriz”' (Tura, 2006, s. 20). Fatma Adile Başer, söz konusu müzik yazarlarını, Türk Mûsikîsinde Abdülbâkî Nâsır Dede adlı çalışmasının Tedkik'te Dönemler bölümünde "Birinci Stralama” ve "İkinci Stralama” (Başer, 2013, s. 62-66) başlıklart altında incelemiştir. Ozan Yarman da; "Tedkik u Tahkik'te geçen 14 makam ile 136 terkibi, akdemunu hariç tutarak" (Yarman, 2008, s. 7-14) sinıflandırmıştır. Ayrıntılı bilgi için bkz. Yarman, O. (2008). Makam Kuyumcuları. İstanbul.

$60 \mid \mathrm{P}$ a g e

www.iiste.org 


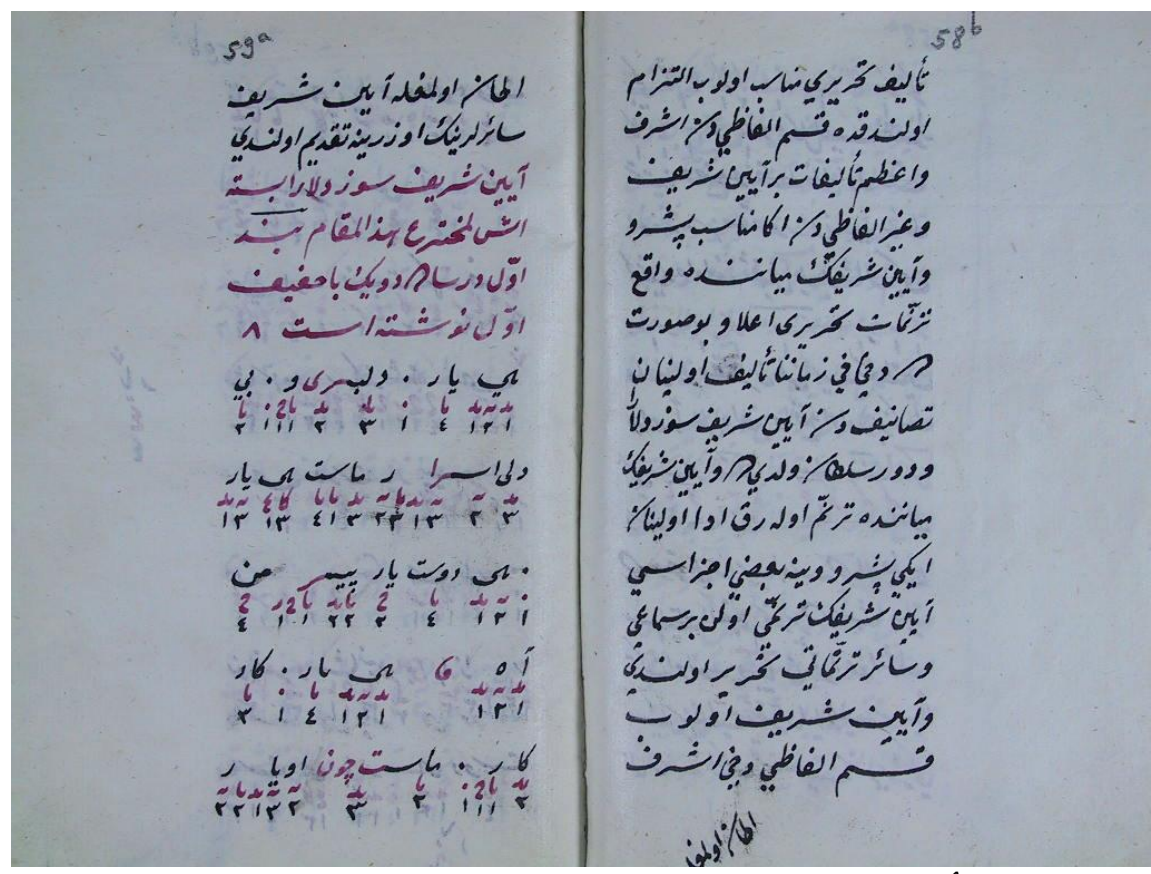

Şekil 1 : Abdülbâkî Nâsır Dede'nin kendi bulduğu müzik yazısıyla Sûzidilârâ Mevlevî Âyini'nin Birinci Bendi'nden bir bölüm (Tetkik u Tahkik, Süleymaniye Kütp., Nafiz Paşa Yazm. Tahrir u Tahririyyetü'l Musıki 1242- 2).

Nâsır Dede, nihâî kertede, icat ettiği müzik yazısı sistemiyle lahn olgusunu paylaşım düzlemine taşımış ve müzikal farkındalık yoluyla erişilebilen sırları dolaşıma sokmuştur. III. Selim'in ihtirâı olan Sûzidilârâ makamından bir Âyîn-i şerîf aktarmayı tercih etmiş, dönemin kudretli bestekârlarının ortaklaşa bestelediği bu eserde görünür hale gelen nağme ve ses aralığ1 estetiğini günümüze ulaştırmıştır.

\subsection{Hâşim Bey}

Mâhûr makamı, Hâşim Bey’in (1815-1868) Mecmûa-i Kârhâ ve Nakışhâ ve Şarklyyât isimli Sultan Abdülaziz'e sunmuş olduğu eserin “Hâş̧im Bey Mecmûası adıyla anılan ikinci baskısı”nın (Yalçın, 2016, s. 18) ${ }^{7}$ İlm-i Edvâra Dâir Risâledir bölümünün Der Ta'rîf-i Makâm-ı Mâhûr başlıklı kısmında şu şekilde açıklanmıştır:

İbtidâ evc, gerdâniye göstererek muhayyer, tiz segâh, tiz çârgâh basarak tekrar dönüp perde perde inerek buselik perdesini hakkıyla icrâ ederek râstda karâr ider. Alafrangada bu makama sol tone ta'bîr iderler (Yalçın, 2016, s. 155)

Aktarılan tanımlamadan anlaşılacağı üzere Hâşim Bey, Mâhur makamını artık armoni düzleminin eksen ve çeken olgularını bünyesinde barındıran ses ilişkileri dahilinde değerlendirme girişimlerinde bulunmaktadır. Bu girişim, lahne odaklanmıș Nâsır Dede ve çevresinin meşruluk zemini olan Nizâm-1 Cedîd'den ayrı olarak Tanzimat döneminin insan ilişkileri bağlamında şekillenmiştir. Bu itibarla söz konusu armoni olgusuyla gerçekleştirilen etkileşimin serencamından bahsetmek yerinde olacaktır.

Osmanlı Devleti, kuruluş sürecini yaşadığg 14. yüzyılın başlarından itibaren askerî, siyâsî, ticârî ve kültürel ilişkileri bağlamında, yerleştiği coğrafî ve jeopolitik konumunun sağladığı avantajlarla aralıklı da olsa Batılı toplumlarla iletişim halinde olmuştur. Zamanla bu iletişim kapsamında yapılandırılan yeni gelişmelere uygun olarak elçiliklerin kurulması, eğitim ve kültürel maksatlı öğrenci gönderimleri, seyyahların ve gözlemcilerin yapıtları sefâretnâmelerle kültür taşıyıcılığı yapmaları, devlet adamlarının karşılıklı hediyeleşmeleri vb. adımlar toplumların karşılıklı olarak birbirlerini tanımalarını kolaylaştırmıştır. Siyâsî, sosyal, kültürel olarak görülen bu etkileşimin doğal bir sonucu da kendini

\footnotetext{
${ }^{7}$ Yalçın, Hâşim Bey Mecmûası adıyla düzenlenen bu ikinci baskının ilk basklya göre muhteva bakımından daha zengin bir güfte mecmuası olduğunu ve ilk baskının Sultan Abdülaziz'e sunulduğunu (Yalçın, 2016 s. 17) ancak Paçacı ise eserin ilk baskısının Abdülmecid'e, ikinci baskısının Abdülaziz'e takdim edildiğini yazar (Paçacı, 2010, s. 46).
} 
müzikal yakınlaşma olarak gösterecek ve Batı müziğini tanımaya yönelik yaşanan ilk gelişmelere de 16 . yüzyılın ikinci yarısında rastlamak mümkün olacaktır. ${ }^{8}$

17. ve 18. yüzyıllarda başlatılan ve Osmanlı Devleti'ni eski gücüne kavuşturmayı ve Batı'da olan yenilikleri ülkeye taşımayı amaçlayarak ilerleyen sslahat çalışmalarının yansıması olan modernleşme, 19. yüzyıla gelindiğinde imparatorluk vasfını korumakta olan devletin birçok katmanında artık daha belirgin bir şekilde görülmüş ve hissedilmiş̧ir. Zira, bu süreçte Batılı devletlerle yaşanan askerî, siyasî, sosyal ve ekonomik yönden artan ilişkiler kaçınılmaz olarak Batı müziğinin Osmanlı Sarayı tarafindan dikkate alınmasına ortam hazırlamıştır. ${ }^{9}$

19. yüzyılın başlarına gelindiğinde Osmanlı saltanat geleneğinden gelen, tarih bilgisi ve estetik birikimi ile göz dolduran II. Mahmut (1808-1839), kendinden önceki dönemlerde yaşanan olaylardan elde ettiği çıkarımların bir sonucu olarak devletin ancak köklü düzenlemelerle eski itibarına kavuşabileceğini ve kurtulacağını düşünüyordu. Yeniçerileri ortadan kaldırmak suretiyle kurmuş olduğu "Asâkîr-i Mansûrei Muhammediye" adındaki yeni ordusu ile askerî yapıyı kontrol altına almayı amaçlayan Sultan II. Mahmut, İtalyanlardan destek alarak müzik teşkilâtını yeniden yapılandırma bağlamında adımlar atmıştır. Doğrudan padişahın şahsına ve saraya bağlı olan Muzika-i Hümâyûn ${ }^{10}$ adındaki bu teşkilât ile

${ }^{8}$ Söz konusu etkileşimlerin tabii bir sonucu olarak Batı müzik dünyası da Osmanlı coğrafyasındaki müzikal estetikle tanışmıştı. Bu bağlamda Batı müzik sanatının önemli bestekarları kompozisyonlarına bu tanışıklı̆̆ın izlerini yansıttılar. Barut (2013), bu yansımayı şöyle dile getirir: "Batı ile etkileşimin ilk örneklerinin, Osmanlı Mehter Takımı vesilesiyle gerçekleştiğini söyleyebiliriz... Mehter müziği Avrupa'da özellikle Avusturya üzerinden yayılmıştı. Bunun da en temel iki nedeni Osmanlı-Avusturya savaşları ve Osmanlıların Avusturya ile oldukça sı k kurdukları diplomatik temaslardı. Mesela 1665 'te elçilik görevi ile bu ülkeye gönderilen Kara Mehmet Paşa, beraberinde getirdiği mehter takımına şehir içinde gösteriler düzenletmişti. Avusturya'daki mehter dinletileri bununla da sınırlı kalmamıştı. Karlofça Anlaşması'ndan hemen sonra diplomatik iliş̧kileri başlatmak amacıyla Viyana'ya gönderilen İbrahim Paşa da benzer bir gösteri düzenletmişti. 1718'deki Pasarofça Anlaşması'nın hemen ardından giden elçimiz Silahdar İbrahim Paşa tarafindan da benzer dinletiler devam ettirildi. 18. yüzyll başlarında Lehistan kralı 2. Augustus, mehter müziğinden çok etkilendi ve dönemin padişahından kendisi için bir mehter takımını Polonya'ya göndermesini rica etti. Leh kralının bu ricası kırılmayarak 12-15 müzisyenli bir ekip Polonya'ya gönderildi. Ancak istek bununla da sinırlı kalmadı. Benzer bir talep Rus çariçesi Anna'dan geldi. Çariçe Anna, İstanbul'da Lale devrinin yaşandı̆̆ bir sırada, 1725 yılında İstanbul'a bir adamını göndererek mehter takımı edindi. 1741 'de Avusturya Habsburgları'nın başkenti Viyana'da da daimi bir mehter takımı bulunuyordu. Bu devleti, hemen kuzeyde bulunan Prusya takip etti" (s. 30). Barut, bu satırların devaminda, "Alla Turca" olarak şöhret bulan bu tarzl "en iyi betimleyen” örnekleri şu şekilde aktarı: "W. A. Mozart (1756-1791), "Saraydan Kız Kaçırma" ̧̧̈̈ perdelik opera, K384 ve Piyano sonatı no. 11, K331 Bölüm 3 (Alla Turca). Üç perdelik bu eser, 16.yy ortalarında Selim Paşa'nın sarayında geçer. Müzik araştırmacıları, Mozart'ın bu operasının bestelendiği dönemde (1781), "Türk Akımı"nın Avrupa'nın genelinde ve özellikle Viyana'da moda olduğundan bahsederler... Bestecinin, Türk temalı bir diğer eseri ise, çok tanınan ve sevilen la majör 11 numaralı K331-300i eser sayll piyano sonatının "alla Turca" başlıkl üçüncü bölümüdür. 2/4'lük vuruşta ve çabukça tempoyla yorumlanan bu bölüm, yeniçeri müziğini Mozart'ın kulağından bizlere duyurur. Mozart'ın bir diğer eseri ise 1780 yllında Salzburg ta bestelenen "Zaide" adli operasidır. Eser; Kanuni Sultan Süleyman Han'ın hareminde bir tutsak olan Zaide ve taşocaklarında çalışan bir köle olan Gomatz'ın aşkını konu alır. Ludwig van Beethoven (1770-1827), op. 113, "Atina Harabeleri"nden "Türk Marşı". Mozart'ın ardindan, 1770-1827 yllları arasında yaşamış olan Ludwig van Beethoven da 1811 yllında yazdiğ op. 113 eser sayll "Atina Harabeleri" adlı eseri içerisinde yer alan bir "Türk Marşı" yazmıştır. Beethoven'ın 1822 yllında dört el piyano için yayımladı̆̆ "Marcia Alla Turca"sı da neredeyse Mozart'ınki kadar popüler olmuş bir başka örnektir (s. 31).

${ }^{9}$ Aksoy bu süreci, 1543 'te imzalanan Osmanl-Fransız antlaşması sonrası I. François' in Kanuni'ye hediye olarak gönderdiği orkestranın Osmanlı Sarayı'nda vermiş olduğu konserlere kadar götürmektedir. Ona göre, Batılı devletlerin İstanbul ve İzmir'de bulunan elçiliklerinin düzenledikleri kendilerine özgü mûsikî ve sanatsal faaliyetleri, İtalyanları İstanbul'daki Venedik elçisinin evinde tertip ettikleri bale gösterileri ve III. Murat zamanında Sultanahmet meydanında gerçekleştirilen bale-pandomim gibi müzikli eğlenceler yeni rastlanan ve Osmanlı toplum yapısı için yabancı olan gelişmelerdi (Aksoy, 1985, s. 1214). Bunlar Batı'da revaçta olmakla birlikte Osmanlı'nın saray çevresi için yeni olan ve ancak ilgi ile karşılanan, merak konusu olan ve asla kayıtsız kalınmamasi gereken bir durum mesabesindeydi.

${ }^{10}$ Toker'in de belirttiği üzere Osmanl toplumunun ilk kez Batı müziği ile tanıştı̆̆ı II. Mahmut dönemi, medreseden orduya ve mehterhâneye değin birçok yeniliğin yaşandiğı, çoğu eski kurumun revize edildiği, kimilerinin kaldırıldiğı ve bu değişimden de mûsikînin fazlasıyla etkilendiği bir dönem olmuştur (Toker, 2016, s. 34). Kara (2010), bu dönemdeki yeni oluşumlardan biri olan Muzika-i Hümâŷ̂n'u; "batı kopyası bando okulu” (s. 5) olarak nitelendirmektedir. Söz konusu nitelendirmeye koşut olarak Muzika-i Hümâyûn yapılanması hususunda negatif ve pozitif yaklaşımların olduğu görülmektedir. Konuya eleştirel yaklaşan Ak, Tanzimat dönemine ait

62 | $\mathrm{P}$ a g e 
Osmanlı'da ilk Batı müziği eğitim ve öğretimi başlamış oluyordu. Bu netice itibari ile Batı ve Türk mûsikîsini öğrenen ilk Türk müzisyenler de yetişme imkânına sahip olmuşlardır. Kolukırık bu durumu Türk müziği ile Batı müziği arasında ilk ayrımın ortaya çıkmaya başlaması olarak değerlendirmektedir (Kolukırık, 2015, s. 6). Gökhan Yalçın ise söz konusu dönüşümü "Batı müzik eğitiminin resmen başladığı bir döneme geçilmiştir” (Yalçın, 2016, s. 58) sözleriyle ifade etmektedir.

Yukarıda zikredilen tarihsel konjonktür dikkate alındığında Osmanlı toplumunun bir dışyüz kimliği haline gelen Türk mûsikîsinin bünyesinde oluşan bu devinim daha isabetli bir şekilde değerlendirilmiş olacaktır. Zira birçoğu yenilgi, toprak kaybı ile biten ve doğal olarak devleti itibar çöküntüsüne sürükleyen bu süreç, askerî alanda yetkin olunmadığı görüşünü etkin kılmıştır. Söz konusu durum Batılı devletlerle olan ilişkilerin farklı boyutlara taşınmasına ve önlemler alınmasına sebep olmuştur. $\mathrm{Bu}$ yönelim sadece askerî alanda değil, aynı zamanda bilimsel, kültürel, sanatsal ve mimarî alanlarda da kendini göstermiştir. Sonuç itibari ile mecburiyet-merak-taklit üçlemi içerisinde öğrenilmeye başlanan ve zamanla tüm Osmanlı toplum yapısını belirli bir düzlemde birleştirecek ya da birleştirmeye namzet olacak yeni bir hayat tarzının da temelleri atılmış oluyordu. II. Mahmut'un devletin merkezi otoriter yapısını güçlendirmeye çalıştı̆̆ı, planlı bir şekilde yenilik aleyhtarlarını etkisiz hale getirdiği, kararlı ve tavizsiz bir şekilde devleti yönetmeye gayret ettiği bir dönem olarak anılan bu süreçte yapılan atılımlarla ilgili olarak Tanör şu ifadeleri sarfetmiştir:

Yeni padişah, tıpkı III. Selim gibi devlet sistemindeki dağılmanın ancak reformlarla önlenebileceği fikrindeydi... Bunların başlıcaları şunlardır: Yeniçeri Ocağı'nın kaldırılarak (1826) askerî gücün siyasal iktidara tâbi kılınması, merkezî bürokratik bir sistemi yeniden kurulması... askerî, idârî ve adlî konularla ilgili sürekli danışma organları kurulması (bunların sonuncusu, bugünkü Danıştay ve Yargıtay'ınkilere benzer yetkilere sahip bir yargı mercii olduğu gibi yasaların hazırlanmasında bir tür "danışma meclisi" rolü de oynuyordu)... (Tanör, 1985, s. 12).

Muzika-i Hümâyûn'un kurulmasına öncülük etmesi ile Batı müziğinin Osmanlı Sarayı'nda öğrenilmesine imkan tanıyan, mûsikî ile meşgul olan ve yirmiye yakın bestesi bulunan, özellikle de "Asâkîr-i Mansûre-i Muhammediye Marşı" ile dikkat çeken II. Mahmut kararlı ve çağdaş yaklaşımlarıyla istikrarlı bir Batılılaşma projesini kendinden sonra gelen Osmanlı padişahı Sultan Abdülmecid'e tabiatıyla devretmiştir. Alimdar, Abdülmecid'in Batılı anlamda müzik eğitimi alan ve piyano çalan ilk padişah olduğunu ve zamanında Muzika-i Hümâyûn'un genişleyip Harem-i Hümâyûn'da uygulanan eğitim müfredatında önemli bir rol oynadığından bahseder (Alimdar, 2016, s.10). Genellikle Batı mûsikîsi dinleyen, opera ve tiyatroya giden ve Aksoy’un bildirdiği üzere maddî-mânevî yönden bu kurumları destekleyen padişah, Donizetti Paşa'dan mûsikîli oyunlar oynamak üzere gençleri yetiştirmesini istemiştir. Geniş yetkilerle ve büyük bir devlet desteği ile yürütmüş olduğu çalışmalarında Donizetti Paşa, Batı mûsikîsinin bir parçası olan bando, orkestra, operet, opera, koro, enstrümantal ya da sözlü ürünleriyle bir program dahilinde çalışmış ve kendisinden sonra göreve getirilen diğer bir İtalyan Callisto Guatelli ve sonrasında İspanyol besteci D'Arenda gibi isimler de dönemin Türk marşlarını besteleyebilecek, Batı müziği nazariyatına yönelik çeviri ve telif eserler yayınlayabilecek düzeyde birçok öğrenci yetiştirebilmeyi başarmışlardır (Aksoy, 1985, s. 1219). Gökhan Yalçın’ın (2016) da belirttiği üzere Donizetti Paşa ile başlanan bu süreçte Batı müzik eğitim sistemi, Türk müziği eğitimi veren eğitmenleri de etkilemiştir (s. 8, 59). Bu etkileşim, Muzika-i Hümâyûn'un İtalyan hocaları, öğrencileri ve bunlarla irtibatlı olmuş müzisyenlerin Türk müziği alanında müzik yazısı, ses sistemi ve armoni gibi hususlarda yeni yaratımlar sergilemelerine zemin hazırlamıştır. Muzika-i Hümâyûn'un hocalarından ${ }^{11}$

Türk kültürünü korurken Batı kültürünü edinme gayesinin burada da görüldügü̈nü ve bu konuda müzisyenliğini takdir ettiği halde padişah II. Mahmut'un yenilik furyasına kapılarak Muzika-i Hümâyûn'u açmasını doğru bulmadığını belirtmekte ve bu kurumun Türk kültürünün önemli bir müessesesi olan Enderûn'u tahrip ettiğini savunmaktadır (Ak, 2009, s. 37). Ancak, Alimdar'ın dikkat çektiği noktadan hareketle; Osmanlı tarihinde Batı müziğine olan ilginin 19. yüzyllda özellikle II. Mahmut'la daha bir gelişim gösterdiği ve kurumsallaştırllmaya çalışıldığı (Alimdar, 2016, s. 5) anlaşılmaktadır. Bu durum göz önüne alındığında Muzika-i Hümâyûn'un varlı̆̆g, Osmanlı Sarayı'nın Batı müziğiyle gerçekleştirmiş olduğu etkileşim olgusu ideolojik perspektiften ziyade toplumsal ve tarihsel zeminler bağlamında değerlendirilmiş olacaktır.

${ }^{11}$ Budak'a (2000) göre; müzikal çalışmaları ile Türk mûsikîsinde yeni bir açıllım ve arayışın öncülügünü başlatmış olan Muzika-i Hümâyûn, Türkiye'de çoksesli müzik eğitimi ve öğrenimi veren ilk konservatuvardır (s. 73). Burada yetişen müzisyenler ve çeşitli ordu birliklerinde kurulan bandolar ilerleyen süreçte çoksesli müzik estetiğinin somut atılımlarının referans isimleri olmuşlardır.

63 | P a g e 
Guatelli, ${ }^{12}$ Necip Paşa gibi isimlerle muhatap olan Hâşim Bey ve Notacı Hacı Emin Efendi bahsedilen bu yeni yaratımların ilk örneklerini veren müzik adamlarıdır. Dellâlzâde İsmâil Efendi ve Hammâmîzâde Dede Efendi gibi üstadların öğrencisi olan ve kendisinden önceki müelliflerin mûsikî geleneğini takip eden Hâş̧im Bey Türk mûsikîsi makamları ile Batı mûsikîsi makamlarını kıyaslamak suretiyle mûsikîyi tanımlamaya çalışmış ve böylece yaşamış olduğu yüzyılın mûsikî ihtiyacını karşılamakla birlikte bu kültür ve birikimin günümüze kadar ulaşmasını sağlamıştır.

Kendisinden önceki mûsikî üstadlarının mirasını devralan ve aynı zamanda güncel armoni tanımlamalarının etkisinde kalan Hâşim Bey, Mâhûr makamını da bu çoklu perspektif dahilinde değerlendirmiş ve ses aralıklarını hem yatay hem dikey belirlenimlere göre şekillendirmiştir. Makale çalışmasının "2. HÂŞIM BEY" başlıklı bölümünün başında aktarıldığı üzere Hâşim Bey Mâhûr makamında evc, gerdâniye, muhayyer, tiz segâh, tiz çârgâh ve buselik perdelerini kullanarak bu makamı râst perdesinde karar ettirmiştir. Kendisinin bu makamı anlatırken kullandığı perdelerden bûselik perdesi dışındakilerin çoğu Râst makamı yapısında da mevcuttur. Her iki makamın Batı müziğindeki karşılığını da sol majör olarak göstermiştir. Bununla birlikte Hâşim Bey’e göre ana dizi do majördür ve bunun Türk müziğindeki karşıllığ ise Çârgâh makamıdır. ${ }^{13}$ Hâş̧im Bey bu durumu şu şekilde ifade eder:

Ma'lûm ola ki, alafrangada isti'mâl olunan makâmât macur tone ki asıl makâm dimektir. Ud ton yani Çârgâh dimektir. Çârgâh perdesinden bed idüb tiz çargâha çıkub yine kendi perdesindeki çârgâh karâr ider. Alafrangada bu makâm cümlesinin esâsıdır. Yani bâlâda zikr olunan Ud tone (Yalçın, 2016, s. 271).

Yukarıdaki satırlardan anlaşılacağı üzere Hâşim Bey'in muhatap olduğu armoni etkileşimi, kendi coğrafyasında şekillenmiş olan bir ses skalasını Batı estetiğinin duyumuyla özdeşleştirmeyi içermekteydi. Yatay düzlemdeki duyum nüanslarının dikey platformla kaynaştırılmasının eleştirel anlamda değerlendirilmesi, bir sonraki kuşağın, Hâş̧im Bey gibi müzik adamlarından kopuş gerçekleştirecekleri en önemli hususlardan biri olacaktı. Ancak tonal armoninin ses aralıklarının hakim olduğu anlayış Hâşim Bey'i takip eden yakın dönemde baskın kanadı oluşturmaya devam etti.

Söz konusu dönemde Osmanlı coğrafyasında "ilk kez Batı notası yayınlayan" Mehmed Emin Efendi, "1983'ten itibaren yayınlanmaya başlayan Ma'lûmât dergisinin ilavesi olarak verilen Chant Turcs başlıklı büyük boy yaprak notalar" (Paçacı, 2010, s. 218) hazırlamıştır. Bu notaların içerdiği şarkılar Zati Bey gibi isimler tarafindan armonize edilmiş bir şekilde aktarılmıștır. Hâșim Bey'in Mecbûr Oldum Ben Bir Güle adlı Bestenigâr şarkııı da fa anahtarııı barındıran bir partisyonla yayınlanmıştır. Burada dikkat edilmesi gereken husus makamsal yapıdaki eserlerin tonal müziğin akor dereceleri ve ses aralıkları zemininde armonize edilmiş olduğudur. Notacı Mehmed Emin Efendi'nin Bir Gül-i Ra'nâya Gönül Bağladım (Malumat, 1895, s. 889) adlı şarkısı bu duruma güzel bir örnek teşkil etmektedir (bkz. Şekil 2).

12 Abdülaziz, öncelikle bandoyu güçlendirerek iyi bir düzeye getirmiş, ardından ordu ve donanmanın gelişmesine büyük bir önem verdiği için bandoculukla da ayrıca ilgilenmiştir. Onun zamanında otuz yll aşkındır saray bando ve orkestrasının başında bulunan Guatelli de öğrencilerini yerli ezgileri örnek alarak millî marşlar bestelemeye yöneltmişstir. Aksoy, "O zamana kadar İtalyan bando repertuvarındaki parçaları icra etmekte olan bandocularımız, ancak Guatelli'nin uyarısından sonradır ki, geleneksel makamların aralıklarını gözeterek, Türk insanını etkileyebilecek yerli motiflerle millî marşlar bestelemeye başlamışlardır” (Aksoy, 1985, s. 1222) demek suretiyle döneme dikkat çekmiştir.

${ }^{13}$ Öztuna, makamların karşılaştırılması hususunda Hâşim Bey'in yanıldı̆̆ına dikkat çekmektedir. Ayrıntılı bilgi için bkz. Öztuna, Y. (2006). Türk Mûsikîsi Ansiklopedik Sözlüğü I, II. Ankara: Orient Yayınları, s. 339.

64 | P a g e

www.iiste.org 


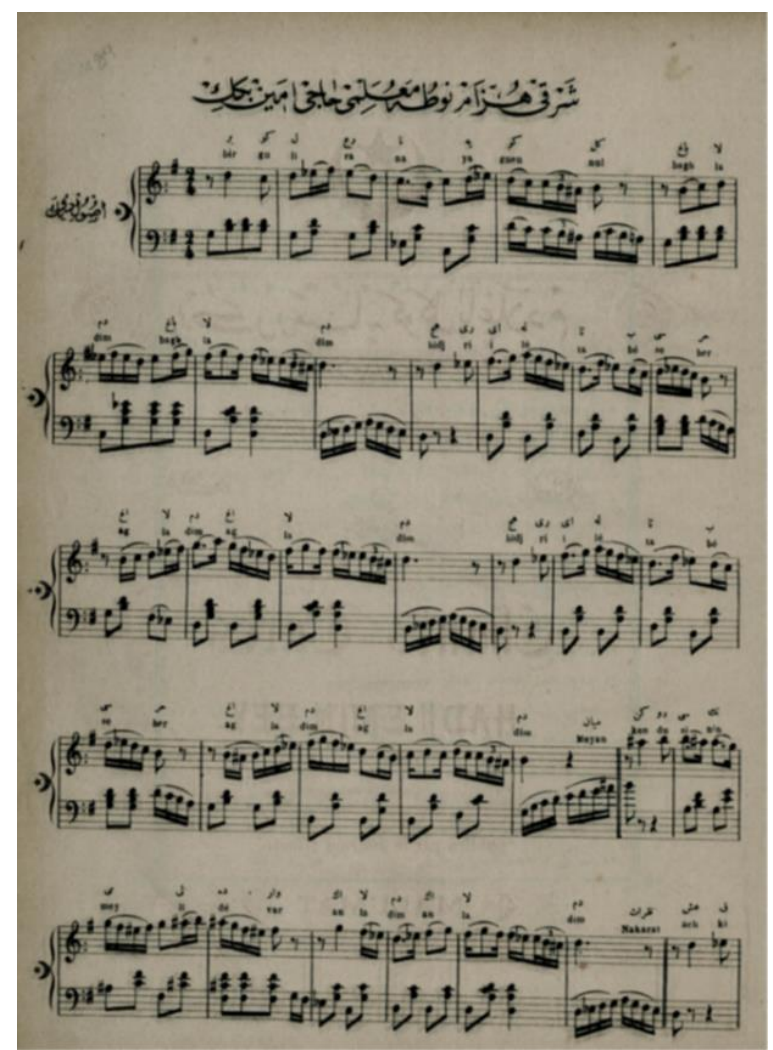

Şekil 2 : Nota Mehmed Emin Efendi'nin Hüzzâm Şarkısı;

Bir Gül-i Ra'nâya Gönül Bağladım (Journal Illustré Turc "Malumat")

Notası aktarılan bu eser, Haşim Bey’in, üçlüsünde kalan sol majörle ilişkilendirdiği Hüzzâm makamı anlayışıyla aynı perspektifte olmak üzere sol majör tonu ses aralıkları ve ilişkileri zemininde armonize edilmiştir.

\subsection{Hüseyin Sadettin Arel}

Hüseyin Sadettin Arel (1880-1955), Mâhur makamını şed makamlar başlığı altında ele almıştır. Buna göre Mâhur makamı Çârgâh makamının şeddidir. Çârgâh makamını oluşturan 4'lü-5'liler ise "T-T-B" ve "T-T-B-T" şeklindeki aralıklara sahip olan Çârgâh renginden hâsıl olmuştur. Çârgâh, Arel için "Türk mûsikîsinde majör ile minörün karşılığı"dır fakat bu durum "benzerlik" zemininde gerçekleşir. Hâşim Bey ve Notacı Emin Efendi'nin müzikal yaratım perspektiflerinden farklı hassasiyetleri haiz olan bu "benzerlik" düzleminin iddiası; "Batı mûsikîsinde aralıkların", Türk müziğinin tabiattan olduğu gibi alınmış olmasının aksine, "tamperaman sebebile biraz değişmesinden ileri”" (Arel, 1948a, s. 9) gelmiş olduğudur. Arel, Tanzimat'tan Cumhuriyet'e geçişin düşünce sancılarını çekmiş ve bu itibarla yeni kurulan ulus-devletin toplumsal ve bireysel söylem inşalarını oluşturan fikir hareketliliğinin önemli simalarından birisi olmuştur. Bu yeni dünyada evrensellik mottosuna uyum becerisi ulusal ve uluslararası ilişkiler demetinde yaşam hakkına sahip olmak anlamına gelmektedir. $\mathrm{Bu}$ itibarla Arel, kendi coğrafyasının ses malzemesinin, varolmanın çağdaş spekülatif zeminine olan uyumunu göstermeye çalışmıştır.

1923 'de Cumhuriyet'in ilanı, niteliği değişen rejimin vatandaş bireyini ulus kimliğinde şekillendirecek bürokratik-kültürel-estetik programın yürürlüğe konması için gerekli şartları sağlamıştı. Cumhuriyet, seküler kimlik ve millilik üzerinden bir ulus yaratma girişimiydi. Bu itibarla takip eden yakın dönemde Türkiye'de önemli sosyo-politik değişimler yaşanmıştı. 1930'ların başından itibaren kitle iletişim araçlarına hakim kamu oyunda milli musikiye hasredilen ilgi yoğunlaşmış ve bu doğrultuda yapılan yayınlarda artışlar görülmüştür. Buna ilaveten musiki alanına millilik söyleminin hakim olmasına yönelik kurumsal ilgiler 1934'ten itibaren ivme kazanmış 10 Haziran 1935'de 'Kültür Merkez Örgütleri ve Ödevleri Hakkındaki 2287 Numaralı Kanunun Bazı Maddelerinin Değiştirilmesine ve Bazı Maddelerin Eklenmesine İlişkin Kanun” yasalaşmıştır (Turan, 1998, s. 134). "Buna göre okullarda ve okul dışında dramatik sanatlarla müzik ve plastik sanat işlerinin, ulusal ülküye uygun yürütülmesine,

65 | P a g e

www.iiste.org 
ulusun bu yönde yetişmesine ve yücelmesine çalışmak başlıca görevler olarak tespit edilir" (Dural, 2019, s. 137). Arel, toplumsal heyecanın söz konusu bu ulusal ideale yöneldiği bir ortamda eğitimin, estetiğin ve sanatsal temsilin, milli ses malzemesini bünyesinde barındıran Türk müziği olgusuyla tesis edilebileceğini öne sürmüştür. Ona göre Türk müziği, ulus-devlet vatandaşının duygularını muhatap alabilecek ve milli bireyin düşünsel-eylemsel yapıp-etmelerine eşlik edebilecek mahiyettedir.

Arel'in yaklaşımına göre, T-T-B-T aralıklarını içeren Çârgâh, Çârgâh'ın ikinci derecesinde bulunan Bûselik ve Kürdî, Râst, Uşşâk, Hicâz temel renklerini içeren Türk müziği, bünyesinde barındırdığı vüsat itibarıyla "Batı musikisinden on kat daha meden̂̂" idi (Arel, 1949, s. 4). Arel, çağdaş hümanist damarın vurgu noktasını oluşturan insanı-insana ait duygu olgusunu merkeze almış ve Türk müziğinin yukarıda adı geçen temel renklerinin, majör-minör renklerine kıyasla, bu merkeze daha uyumlu olduğunu ileri sürmüştür. Bu itibarla nevâ perdesi üzerinde Râst rengini kullandığı Râst makamıyla Çârgâh rengini kullandığı Mâhur makamına modern bireyin katharsis olgusunda farklı görevler yüklemeyi tercih etmiştir. Arel'e göre, T-K-S-T aralıklarını içeren ve bu anlamda nevâ üzerinde evc perdesinin kullanımını gerektiren Râst rengi; "ciddiyet, kibarlık, nahvet, vekar, nezaket, hürmet ile bunlara yakın hislerin tasvirine hizmet" ediyorken, T-T-B-T aralıklarını içeren ve bu bakımdan nevâ üzerinde mâhur perdesinin kullanımını gerektiren Çârgâh rengi; "sadelik, basitlik, masumluk, şenlik, adilik, cesaret, şecaat, azimkârlık ile bunlara benzer manaları ifade etmeye elverşilidir” (Arel, 1952a, s. 5).

Arel için müzikal makam, dörtlü-beşlilerin duyguyla tam anlamıyla bütünleştikleri bir olgudur. Arel'e göre bu özelliği barındıran en temel yapılar basit makamlardır. Arel, basit makamı; "bir tam dörtlü ile bir tam beşlinin veya bir tam beşli ile bir tam dörtlünün yan yana gelmesinden hâsıl olup da güçlüsü ek yerinde görünen ve birinci-dördüncü dereceleri arasında tam dörtlü nispeti bulunmakla beraber kalış1 da tam bir istirahat duygusu veren" (Arel 1948b: 3) bir yap1 olarak tanımlar. Basit makamlar, bu nitelikleriyle insan duygularını ifade etmede başvurulacak en temel yapılardır. Basit makamlar içerisinde bu amac1 yerine getirebilecek en uygun yapı ise Çargâh'tır. Hâşim Bey, Çargâh'1, do majörün Türk müziğindeki karşılığı ve bu itibarla "asıl makam" olarak nitelendirmişti. Arel ise bu nitelendirmeden farklı olarak Çargâh'1, kendisinin belirlemiş olduğu basit makam tanımı çerçevesinde bulunduğu ve en temel forma sahip olduğu için ana dizi olarak kabul etmiştir. Buna göre; "Çargâh makamının dizisi içinde Çargâh dörtlüsü (T T B) dokuz defa ve Çargâh beşlisi (T T B T) sekiz defa tekerrür” eder. "Kendi dizisi çevresinde dörtlüsü ile beşlisi bu kadar çok tekerrür eden başka hiçbir makam yoktur" (Arel 1952b: 134). Bununla birlikte makamın dizisini oluşturan Çargâh dörtlüsü ve beşlisinde bulunan "sadelik, basitlik, masumluk, şenlik, adilik, cesaret, şecaat, azimkarlık gibi manalar, bu dörtlü ve beşlilerin içinde bulunan Buselik ve Kürdî çeşnilerinden gelen tesirlere göre ya kuvvetlenir, ya zayıflar, yahut da büsbütün değişir". "Mesela Çargâh dizisindeki Buselik dörtlü ve beşlisi üzerinde fazlaca gezinilirse teessür, hüzün, korku, utanma, yorgunluk, sevgi, şefkat gibi duygular işe karıştırılmış olur” (Arel, 1952c, s. 163-164).

Arel, basit makamların ve özellikle Çargâh'ın, çağdaş duygu olgusuyla olan uyumunun mürekkep makam yapılarında da mevcut olduğunu dile getirmiştir. Arel için geçkinin yapılma sebeplerinin başlıca amillerinden birisi; "hususi bir fikri veya bir duyguyu dinleyicilere ulaştırmak”tır (Arel 1993: 121). Söz konusu bu müzikal hareketliliğe imkan tanıyan mürekkep makam yapısı ve çeşitleri Arel tarafından şöyle tarif edilir:

a) bir sekizli içindeki geçkiden veya geçkilerden doğan ve dizilerini bir sekizli halinde göstermek mümkün olan, b) bir sekizliden daha geniş saha içindeki geçkiden veya geçkilerden doğan ve dizilerini bir sekizli halinde göstermek mümkün olmayan, c) her hangi bir makamın dizisi sonuna bir kuyruk tarzında ya Kürdî veya Buselik geçkisinin eklenmesinden doğan... (Arel, 1948b, s. 3-4).

Ayrıca Arel, yukarıda yaptığı tanıma uyan makam yapılarından hangilerinin müzikal yaratımda güncel olarak kullanılacağını belirleyecek olan kıstasın da yine duygu olgusu olduğunu vurgulamıştır: "Maamafih yaşayacağını muhakkak veya muhtemel gördüğüm makamları kendi zevkime göre seçmiş değilim. Onların her birinde kulağa şiddetle çarpan bir hususiyet, ve gayet kuvvetli bir duygu hamulesi vardir" (Arel, 1993, s. 280).

Arel aynı şekilde şed makam konusunu ele alırken içinde bulunduğu estetik ve toplumsal gereklilikleri gündemine almış; "herhangi bir makamın şeddini ondan başka bir makam imiş gibi ayrı bir isimle anmak doğru değildir" görüşünü benimsemiştir. Bu doğrultuda, Batı müziğinde majör ile minörün şedlerinin kullanılmasının duyguyu muhatap almada elde ettiği başarıları adres göstermiş ve şed olgusunun "Çargâh, Buselik, Kürdî, Zirgüle, Hicaz, Segâh” makamlarına ve "bu beş makamın bütün mümkün şedlerine değil, yalnız bir veya birkaçına münhasır” kılınmasına karşı çıkmış bunun yerine "24 gayri

66 | $P$ a g e

www.iiste.org 
müsavi taksimatlı umumi dizinin müteaddid perdelerine" (Arel, 1993, s. 281, 282) uygulanmasını tavsiye etmiştir. Arel, sonuç olarak, ayrı ayrı sınıflandırdığı basit, mürekkep ve şed makamları armoni dünyasının en nitelikli malzemeleri olarak düşünmüştür. Arel, armoni olgusu için en elverişli malzemenin, matematiksel ve estetik bağlamların referanslığında Türk müziğinde bulunduğunu dile getirmiştir. Bu yaklaşımı doğrultusunda Avrupa müzik yazısı "nota" üzerinde yeni yaratımlar ortaya koymuştur. Arel'e göre bu noktadan itibaren yatay ve dikey müzikal hareket insan duygularının çeşitli tezahürlerine uyum sağlayacak şekilde T, K, S, B gibi simgelerle karşılanan ses aralıklarının ilişkilerine göre belirlenmelidir. Arel, söz konusu aralık ve renk estetiği bağlamında eserler bestelemiş ve revize ettiği müzik yazısıyla bu eserleri notaya aktarmıştır (bkz. Şekil 3).

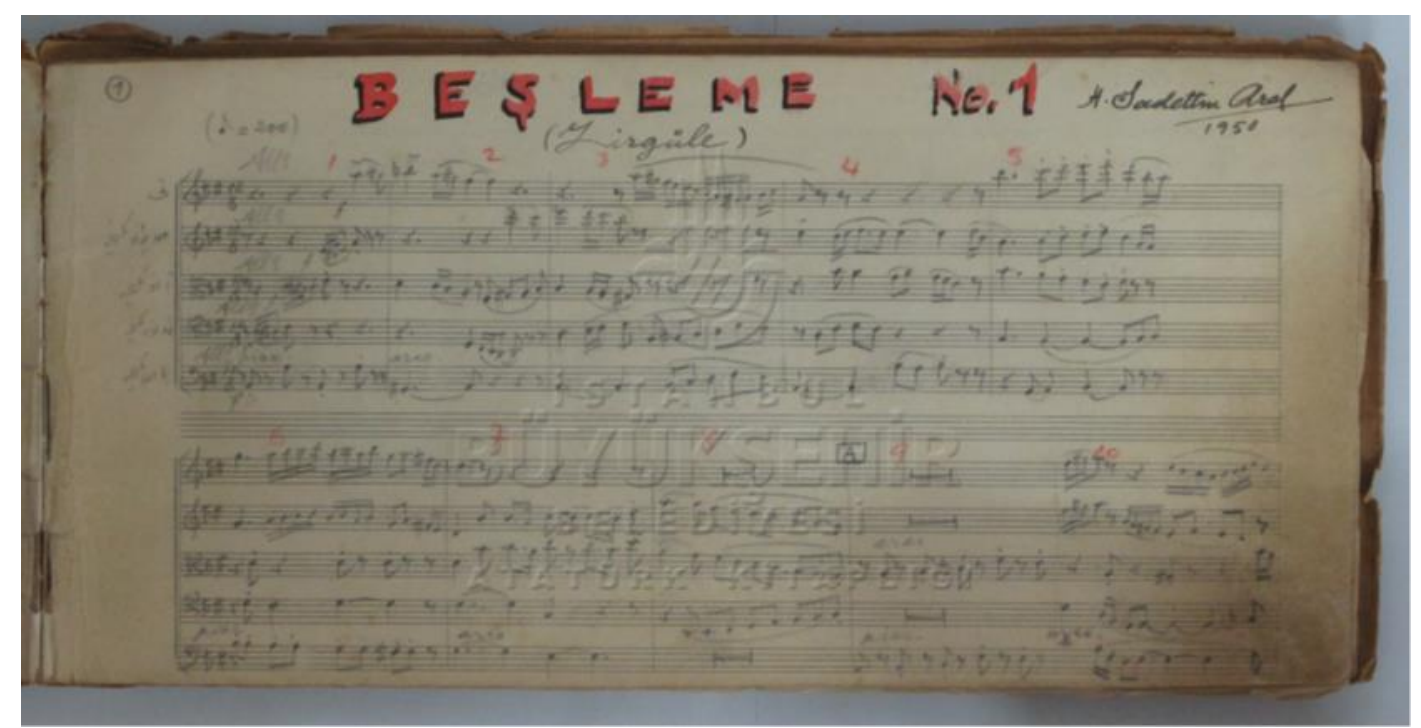

Şekil 3 : Arel'in el yazıslyla, Zirgüle makamında Beşleme

(IBB Atatürk Kitaplığ Sayısal Arşiv ve e-Kaynaklar).

Arel, Türk müziği alanında farklı anahtarları ve ses sahalarını gündemine alarak "Çârgâh, Bûselik, Kürdî, Râst, Uşşâk, Hüseynî, Nevâ, Hicâz, Hümâyûn, Uzzâl, Zirgüle, Karcığar, Sûzinâk” (Arel, 1993, s. 40) olarak belirlediği temel makamların dikey anlamda da ele alınması gerektiğini vurgulamıştır. Bu itibarla söz konusu temel makamların referanslığında yapılandırılan mürekkep ve ayrıca Mâhûr gibi şed makamların ses aralıkları, barındırdığı renkler ve işlevleri Türk müziğinin evrensel malzemesini temsil etmektedirler.

\section{Sonuç}

Makale çalışması dahilinde, Abdülbâkî Nâsır Dede, Hâşim Bey ve Hüseyin Sadettin Arel'in müzikal yaratımları bağlamında Mâhur makamının tanımlanış şekli sorgulanmıştır. Sorgulamanın ilişkili olduğu olgular düşünsel ve tarihsel zeminlerdir. Düşünce sistemleri kapsamında tarihselliğin irdelendiği ve bu anlamda yeni sınırlara sahip olduğu perspektiflerle etkileşim içerisinde olan makale çalışması, Descartes ile başlayan ve Kant, Hegel, Nietzsche gibi düşünürlerin belirli eleştirel hamleleriyle şekillenmiş olan yaklaşımlarla etkileşim içerisindedir. Bu etkileşim, insan düşünce ve eylemlerinin değerlendirilmesinde vurgunun tarihe yapılması noktasında bahsedilen yaklaşımlarla ortak paydaya sahiptir. Makale çalışması, bu ortak paydanın dişında da tarihselliği, sorgulama neticesinde karşılaşılan somut veriler kapsamında değerlendirmektedir. Buna göre, verilerin sorgulanmasında karşılaşılan süreklilik, kopuş ve farklılık olguları herhangi bir tözsel, sabit vb. hedeflerin araçları değildirler. Bilakis söz konusu olgular, üzerinde yoğunlaşılması gereken somut adresler olarak ele alınmaktadırlar.

Makalenin konusunu oluşturan bu somut adreslerden biri olan ve Nizâm-1 Cedîd Dönemi'nde yaşamış bulunan Abdülbâkî Nâsır Dede, Mâhur makamını, söz konusu dönemin toplumsallığında şekillenmiş olan Yenikapı Mevlevîhânesi'nin anlam dünyasına göre değerlendirmiştir. Bundan hareketle Mâhur-1 sagîr, Mâhur-1 kebîr, Mâhurek ve Mâhur-1 kebîr-i kadîm birleşimlerini zikretmiş ve bu birleşimlerin ses malzemesini, şeyhlik statüsünün esrâra erişime imkan tanıyan müzikal malzemesi olan lahn olgusu çerçevesinde anlamlandırmıştır. Evc, mâhur, segâh, buselik gibi perdeleri ve Râst gibi renkleri bu lahn olgusu dahilinde ele almıştır. Hâşim Bey ise Mâhur makamını, Tanzîmât Dönemi’nden itibaren düşünsel

67 I P a g e

www.iiste.org 
anlamda yaşanan etkileşimin ağırlığını hissettirdiği bir vizyondan hareketle tanımlamıştır. Bu itibarla kendisi söz konusu makamı, Batı müziğinin sol majörüne koşut olarak değerlendirmiştir. Nâsır Dede'nin yukarıda aktarılan anlam dünyasıyla şekillendirdiği perdeler ve renkler bu sefer Muzika-i Hümâyûn'un etkilerini üzerinde hisseden Hâşim Bey tarafindan çok farklı bir zeminle ilişkilendirilmiş̧ir. Buna göre, Türk müziğindeki Çârgâh makamı ana dizi do majörün karşılığıdır.

Çârgâh makamı, Hüseyin Sadettin Arel'de ise benzerlik perspektifi doğrultusunda anlam kazanmıştır. Cumhuriyet'in ulus-devlet bireyinin müzikal malzemesi olarak Çârgâh rengi artık Batı müziğinin majör yapısının benzeridir ve bu benzerliğin getirmiş olduğu yeni imkanlar sayesinde daha başka bir çok renk de gündeme gelmiştir. Arel'e göre Batı müziğinin majör ve minörüne karşllk Türk müziği Çârgâh, Bûselik, Kürdî, Râst, Uşşâk ve Hicâz temel renklerine sahiptir. Bu itibarla Arel, Mâhur makamını Çârgâh'ın şeddi olarak tanımlamış ve makalenin konusunu teşkil eden diğer iki ismin de kendi bağlamları dahilinde ele almış oldukları perdeleri Çârgâh'ın sahip olduğu benzerlik düzlemine göre şekillendirmiştir. Bu anlamda Mâhur makamı Râst makamından ayrı bir yapıdır ve insan duygularının çeşitliliğine hitap etmektedir. Arel, Mâhur makamında Nevâ perdesi üzerinde Çârgâh rengini ve bu itibarla mâhur perdesini kullanmış, Râst makamında ise Nevâ perdesi üzerinde Râst rengini ve bu doğrultuda evc perdesini tercih etmiş̧ir. Kendisi, tüm bu perde ve renk çeşitliliğini yatay ve dikey düzlemde değerlendirmiş ve armoninin katharsis zemininde insan duygusuyla kurmuş olduğu etkileşimi müzikal yaratımın gündemine dahil etmiştir.

Makale çalışması, kendine has sorgulama yaklaşımıyla şekillendirdiği düşünsellik ve tarihsellik perspektifinden hareketle yukarıda zikredilen üç referans müzik adamının Mâhur makamı tanımlarını değerlendirmiştir. $\mathrm{Bu}$ değerlendirme kapsamında karşlaşılan olgular süreklilik, kopuş ve farklılık olmuştur. Her bir müzik adamının kendi toplumsallık ve bireysellik düzleminde söz konusu makamla kurmuş olduğu ilişki an itibarıyla etkileşim kurulabilecek somut veriyi oluşturmaktadır. Bu bakımdan makale dahilinde nihai olarak, karşılaşılan farklılığın kendisiyle yetinilmekte ve içinde bulunulan anın da düşünsel-tarihsel anlamda değerlendirilmesi vurgulanmaktadır. Bu itibarla Mâhur makamı ve benzeri müzikal olgulardaki yaratım heyecanının yaşanılan zamanda da taze tutulmasının gerekliliğinin altı çizilmektedir.

\section{Kaynakça}

Abdülbâkî Nâsır Dede. Tedkîk ü Tahîk. Süleymaniye Kütüphanesi, Nafiz Paşa, nr: 1242/1.

Tahrîriyyetü'l-mûsikî, Süleymaniye Kütüphanesi, Nafiz Paşa, nr: 1242/2.

Ak, Ahmet Ş. (2009). Türk Mûsikîsi Tarihi. Ankara: Akçağ Yayınları.

Aksoy, B. (1985). "Tanzimat'tan Cumhuriyet'e Musiki ve Batıllaşma". Tanzimattan Cumhuriyet'e Türkiye Ansiklopedisi V. İstanbul: İletişim Yayınları, C. 5, 1212-1237.

Alimdar, S. (2016). Osmanlı'da Batı Müziği. İstanbul: Türkiye İş Bankası Kültür Yayınları.

Arel, H., S. (1948a). "Bir Musiki Masalı". Musiki Mecmuası, S. 3, s. 8-9.

(1948b). Musiki Terimleri 1. Musiki Mecmuası, S. 8, s. 3-6.

(1952a). Makamlardaki Duygu Unsuru II. Musiki Mecmuasl, S. 48, s. 3-4.

(1952b). Makamlardaki Duygu Unsuru V. Musiki Mecmuasl, S. 53, s. 131-134.

(1952c). Makamlardaki Duygu Unsuru VI. Musiki Mecmuast, S. 49, s. 163-165.

(1949). “Niçin Türk Musikisine Taraftarım?”. Musiki Mecmuası, S. 11, s. 3-5.

Yayınları.

(1993). Türk Musikisi Nazariyatı Dersleri. (O. Akdoğu, Haz.), Ankara: Kültür Bakanlı̆̆1 
Barut, Z. (2013). Türk Müzik Kültürünün Batı Müziği'ne Yansıması Üzerine Bir İnceleme. Uluslararası Sosyal Araştırmalar Dergisi, C. 6, S. 28, s. 28-33.

Başer, F. A. (2013). Türk Musikisinde Abdülbâkî Nâsır Dede. İstanbul: Fatih Üniversitesi Konservatuar Müdürlüğü Yayınları.

Budak, Ogün A. (2000). Türk Müziğinin Kökeni-Gelişimi (Deneme). Ankara: Kültür Bakanlığ1 Yayınlar1.

Bumin, T. (2013). Hegel, Bilinç Problemi Köle-Efendi Diyalektiği, Praksis Felsefesi. İstanbul: YKY.

Dural, S. (2019). Bir Illişkisel Üretim Süreci Olarak Müzikal Yaratım; AbdülBâkî Nâsır Dede ve Hüseyin Sadettin Arel Örneği. (Doktora Tezi). İstanbul Teknik Üniversitesi, Sosyal Bilimler Enstitüsü, Müzikoloji ve Müzik Teorisi Anabilim Dalı, İstanbul.

Kolukırık, K. (2015). Türk Müzik Tarihinde Dârü'l-elhân ve Dârü'l-elhân Mecmuası. Kırşehir: Barış Kitabevi.

Küçükalp, K. (2008). Batı Metafiziğinin Dekonstrüksiyonu: Heidegger ve Derrida. Bursa: Sentez Yayınları.

Notacı Mehmed Emin Efendi. (1895). Journal Illustré Turc “Malumat”. İBB Atatürk Kitaplığ1 Sayısal Arşiv ve e-Kaynaklar.

Öztuna, Y. (2006). Türk Mûsikîsi Ansiklopedik Sözlüğ̈̈ I, II. Ankara: Orient Yayınları.

Paçacı, G. (2010). Osmanlı Müziğini Okumak [Neşriyât-ı Musikî]. İstanbul: T.C. Kültür ve Turizm Bakanlığı Yayını.

Tanör, B. (1985). “Anayasal Gelişmelere Toplu Bir Bakış”. Tanzimattan Cumhuriyet'e Türkiye Ansiklopedisi I. İstanbul: İletişim Yayınları, C. 1, s.10-26.

Toker, H. (2016). Elhân-1 Aziz Sultan Abdülaziz Devrinde Sarayda Mûsikî. İstanbul: TBMM Milli Saraylar Yayinı.

Tura, Y. (2006). Tedkîk ü Tahkîk-İnceleme ve Gerçeği Araştırma- Nâsır Abdülbâkî Dede. İstanbul: Pan Yayıncilik.

Turan, N., S. (1998). Türkiye'de Çă̆daşlaşma ve Müzik. (Yayınlanmamış Yüksek Lisans Tezi). İstanbul Üniversitesi Sosyal Bilimler Enstitüsü, İstanbul.

Yalçın, G. (2016). 19. Yüzyıl Türk Musikisinde Hâşim Bey Mecmuası Birinci Bölüm Edvâr.

Yarman, O. (2008). Makam Kuyumculart. İstanbul. 